\title{
Water Content of Honey Bee Collected Pollen from 50 Plants from Bulgaria
}

\author{
Zheko Radev* \\ Cosmocert SA - Certification Cervices, Greece \\ *Corresponding author: Zheko Radev, Cosmocert SA - Certification Cervices, Greece
}

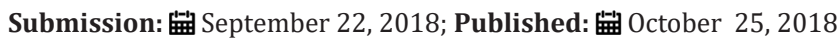

\begin{abstract}
The water content of honey bee-collected pollen was determined by a method of drying. A list of the water content in the pollen of 50 identified plant species was made. The percentage of water content in the examined bee-collected pollen samples ranged between 9.69\% for Centaurea calcitrapa and $23.12 \%$ for that of Crepis sp. and the average was $17.35 \%$. Pollen from various botanical species has a different water content. There are also differences among different species of plants of the same family. The anemophilous species- Juglans regia and especially Chenopodium sp. and Atriplex patula had one of the lowest water contents, while Plantago sp. and specifically Amaranthus retroflexus had one of the highest water contents. The introduced plant Zea mays, Salix sp.- which was regarded as an anemophilous plant in this analysis and Morus nigra occupied a middle position in the results. No differences were found in the water content of pollen between the anemophilous and the entomophilous species. Ecological factors, especially rainfalls, can also affect water content.
\end{abstract}

Keywords: Bulgaria; Honey bee; Melissopalynology; Method of drying; Pollen; Water content

\section{Introduction}

Water plays an important role in the diet of honey bees, but is not essential contained in the pollen. According to [1] the percentage value of moisture in the pollen species collected by bees, was found to be $11 \%$ and in the range of 7-18\% [2] found that the average value of moisture content in ten samples of dried pollen originatin from isolated plant species was 7.4\% [3] estimated an average of $16.48 \%$ moisture in pollen. The average moisture of freshly collected and dried pollen calculated by [4] was $18.3 \%$ and $6.2 \%$, respectively. According to [5-7] the amount of moisture in pollen plays an important role for the preservation and storage of products, while [8] has proposed to add the amount of moisture in pollen to the quality criterion. Many methods have been used to determine the moisture in bee products. For estimating the moisture in royal jelly, the refractive index is used (Refractometric analysis) [3]. However, the results are not very satisfactory because of the high error calculation and small repetitions in this method [9]. The two widely used methods for determining the amount of moisture in the pollen are by gravity (gravimetric method) and Karl Fischer titration. It is significantly easier to analyze pollen samples by using the gravity method because of its accuracy and simplicity. On the other hand, Karl Fischer's method is comprehensive and fast, but quite expensive compared to the abovementioned method [4]. It is necessary to know the water content of pollen in order to determine the amount of protein content, lipids, sugars, minerals and other components in the dry matter. In the available literature, there is no information on the water content of identified honey bee-collected pollen in Bulgaria.

\section{Materials and Methods}

Pollen traps were placed in five bee hives and the pollen pellets were harvested every 2 days from April to September 2014 in the area of Belozem (42.201860, 25.049330), Bulgaria. The climate is transitional-continental. Around 75 samples of the bee-collected pollen were separated, according to colour, shape and texture. The pollen samples were labelled for identification and stored in separate vials in a freezer at $-20^{\circ} \mathrm{C}$. The plant species of each pollen pellet was identified through a microscopic examination of the grains. Melissopalynology analysis was carried out using a similar methodology to that of [10]. Each identified pollen sample was placed on a slide with a drop of isoglucose and added fuchsin. The slides were then dried at a temperature not exceeding $40^{\circ} \mathrm{C}$ and fixed with Entelan ${ }^{\mathrm{TM}}$ (Entelan Microscopy, Karlsruhe, Germany). To identify the pollen, the database of the laboratory of ApicultureSericulture of the Agricultural school of Aristotle University in Thessaloniki, Greece, and a personally created database of the plants from the study area have been used for reference. The method of drying at $103^{\circ} \mathrm{C}$ was used for the determination of moisture content in the pollen samples. A quantity of $1 \mathrm{gr}$ of pollen was accurately weighed in a porcelain-evaporating dish and was placed at $103^{\circ} \mathrm{C}$ in a oven, for 2.5 hours. The water content was 
estimated as the difference in weight of the dried samples before and after introduction into the drying oven.

Water $\%=M-M_{1} / M-M_{2} \times 100$
M- dish and sample weight (gr)

$\mathrm{M}_{1}$ - mass weight with sample after drying (gr)

$\mathrm{M}_{2}$ - weight before adding the sample analysed (gr)

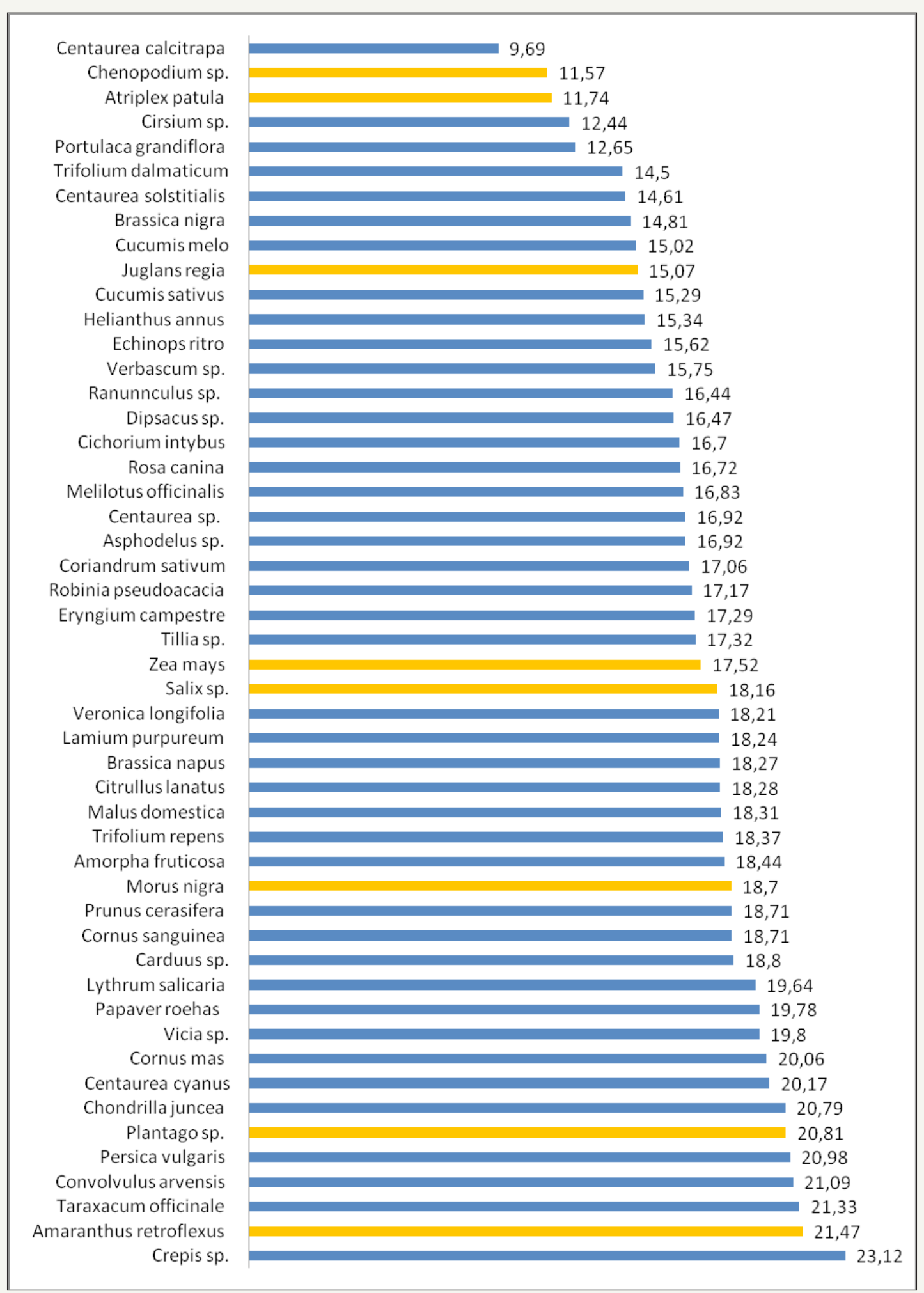

Figure 1: Water content (\%) of pollen of 50 different plant species.

Yellow: anemophilous plants; Blue: entomophilous plants. 


\section{Results and Discussion}

Based on the analysis, a list with the water content of beecollected pollen of 50 identified plant species has been compiled (Figure 1). The results underline the fact that pollens from various botanical species have greatly different water content The percentage value of total water content in the examined bee-collected pollen samples ranged from $9.69 \%$ for Centaurea calcitrapa to $23.12 \%$ for that of Crepis sp. and the average was estimated at $17.35 \%$. Family Asteraceae included the species with the lowest $9.69 \%$ for Centaurea calcitrapa and the highest $23.12 \%$ for Crepis sp. water content (Figure 1). The different types of honey flora have a different water content of pollen, therefore the spectrum of water content of the pollen in the area can vary to a very large degree. The anemophilous species- Juglans regia and especially Chenopodium sp. and Atriplex patula had one of the lowest water content values, while Plantago sp. and specially Amaranthus retroflexus had one of the highest water contents. The introduced plant Zea mays, Salix sp. which was regarded as an anemophilous plant in this analysis and Morus nigra had values of $17.52 \%, 18.16 \%, 18.7 \%$ respectively (Figure 1). They occupy a middle position in the results. There are also differences among different species of plants of the same family. This study has not made a systematic comparison between insect-pollinated and wind-pollinated plants, but significant differences in the water content of the two groups were not found in the species analyzed. The average water content of anemophilous plants was $16.88 \%$, whereas in entomophilous plants it was $17.44 \%$ (at $p \leq 0.05, p=0.6$, Anova: Single factor).

The values of water content of pollen measured in this study are comparable with the results of other researcher, even though some species were shown to contain more and others less water in their pollen than in previous publications. The water content found in this study was higher than the previously reported for Taraxacum officinale, Robinia pseudoacacia, Papaver rhoeas, Ranunculus sp, and Carduus sp. The water content of pollen presented in this research was lower for the species Verbascum sp. and Chenopodium sp. The water content of Cichorium intybus was estimated to be very similar to that found by [3]. The differences between water content of pollen observed in this study and the work of [3] could be attributed to the differences in geographical origin and climate zone. The dynamic change of ecological factors, especially rainfalls, can also influence water content. Pollen is the source of protein necessary for vital processes of the honey bees [11]. The determination of moisture content in the pollen is used to reveal the remaining dry matter content and to express the protein and other components as a percentage of the dry matter. The determination of water content could be used as a parameter for pollen quality. The knowledge of the quality of the local pollen flora is very important for beekeeping.

\section{References}

1. Iannuzzi J (1993) Pollen: food for honey bee and man? American Bee Journal 133(8): 557-563.

2. Muradian L, Pamplona L, Coimbra S, Barth O (2005) Chemical composition and botanical evaluation of dried bee pollen pellets. Journal of Food Composition and Analysis 18(1): 105-111.

3. Liolios V (2010) Record of pollen flora, protein content and sugar composition in bee-collected pollen. M Sci Thesis 61-67.

4. Szczesna T, Chmielewska H, Was E, Skubida P (2009) Water determination in bee products using the Karl Fischer titration method. Journal of Apicultural Science 53(2): 49-55.

5. Szczesna T, Chmielewska H, Chmielewski H (2002) Sugar composition of pollen loads harvested at different periods of the beekeeping season. Journal of Apicultural Science 46(2): 107-115.

6. Szczesna T (2006) Protein content and amino acid composition of bee collected pollen from selected botanical origins. Journal of Apicultural Science 50(2): 81-90.

7. Szczesna T (2007) Study on sugar composition of honey bee-collected pollen. Journal of Apicultural Science 51(1): 15-22.

8. Campos M, Cuhna A, Markham K (1996) Bee pollen composition, properties and applications. Proceedings of an international Conference on bee products properties, applications and apitherapy, Tel Aviv Israel 1: $93-100$

9. Serra-Bonvehi J (1991) Estudio de la adulteracione de la jalea real con otros productos de la abeja y agua. Invest Agraria 6(2): 99-111.

10. Louveaux J, Maurizio A, Vorwohl G (1978) Methods of Melissopalynology. Bee World 59(4): 139-157.

11. Dietz A (1975) The hive and the honey bee. J Printing Co Illinois.
Creative Commons Attribution 4.0 International License

For possible submissions Click Here

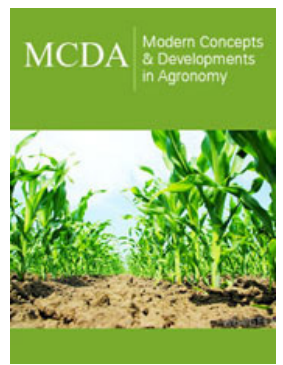

Modern Concepts \& Developments in Agronomy

\section{Benefits of Publishing with us}

- High-level peer review and editorial services

- Freely accessible online immediately upon publication

- Authors retain the copyright to their work

- Licensing it under a Creative Commons license

- Visibility through different online platforms 